\title{
Kreativitas Seniman Tingkilan Kutai Kalimantan Timur
}

\author{
Eli Irawati \\ Institut Seni Indonesia (ISI) Yogyakarta \\ Jl. Parangtritis Km 6,5 Yogyakarta
}

\begin{abstract}
For Kutai society, the term of Tingkilan has two meanings: first, as a betingkilan activity, that is performed by the performers through chanting the songs, whereas the lyrics are in the form of pantun which are intended as satire. Second, betingkilan is also known as a kind of musical ensemble. The creativity of Tingkilan playings are inseparable from some aspects that influenced it, either external or internal factors. The external aspects are connected with the Kutai society's views about their concepts of life, customs, and traditions, due to geographical situations, history, and the advance of science and technology. Whereas the internal aspects that influence the improvement of Tingkilan playings are the efforts of the artists themselves to create new works productively that can accommodate the contemporary Kutai society's preferences which of course need the artists creative touch.
\end{abstract}

Keywords: Creativity aspects, Tingkilan, Kutai, and ethnomusicology

\begin{abstract}
ABSTRAK
Tingkilan dalam masyarakat Kutai memiliki dua pengertian yaitu sebagai sebuah aktivitas betingkilan atau mendendangkan lagu yang berisi sindiran lewat pantun dan juga untuk penyebutan sebuah ansambel musik. Kreativitas Tingkilan tidak terlepas dari beberapa faktor yang mempengaruhinya baik yang disebabkan oleh faktor eksternal maupun faktor internal. Faktor eksternal yang secara tidak langsung dapat mempengaruhi pandangan masyarakat tentang konsep hidup, adat, dan tradisi masyarakat Kutai disebabkan oleh letak geografis yang strategis, sejarah, dan kemajuan di bidang ilmu pengetahuan dan teknologi. Adapun faktor internal yang mempengaruhi perkembangan Tingkilan adalah adanya upaya dari para senimannya untuk produktif menciptakan karya-karya baru yang bisa mengakomodir dari selera masyarakat Kutai zaman sekarang yang tentunya membutuhkan sentuhan olah kreativitas dari para senimannya.
\end{abstract}

Kata kunci: Faktor-faktor kreativitas, Tingkilan, Kutai, dan etnomusikologi

\section{PENDAHULUAN}

Tingkilan merupakan salah satu kesenian tradisional yang berkembang pada masyarakat Kutai, Kalimantan Timur. Ansambel Tingkilan di kalangan masyarakat Kutai dikenal pula dengan sebutan musik Gambus, namun istilah atau penyebutan musik Gambus tidak begitu populer di kalangan masyarakat Kutai. Penyebutan ini disesuaikan dengan lagu yang dibawakan oleh kelompok musik tersebut yang kebanyakan berupa sindiran dan gurauan yang lazim disebut dengan Tingkilan dalam masyarakat Kutai. Tingkilan termasuk ke dalam budaya pesisir Kalimantan karena berawal 
dari lahirnya penyampaian hasrat pelaku musik atau peningkil untuk melepaskan diri dari lelah dan mengisi waktu luang sehabis behuma atau bertani, berdagang, nelayan, dan juga untuk pelepas lelah setelah bekerja dengan rutinitas yang padat.

Secara etimologi Tingkilan berasal dari kata kerja tingkil yang berarti sindir atau menyindir, mendapat akhiran-an menjadi kata benda Tingkilan. Penyajian Tingkilan biasanya dilakukan secara sendirian atau berkelompok dengan cara menyanyikan lagu-lagu yang diiringi oleh ansambel Tingkilan. Oleh karena itulah masyarakat Kutai mengartikan Tingkilan sebagai sebuah musik yang mempunyai peranan untuk menghibur mereka di saat senggang dan dipergunakan dalam berbagai kegiatan atau acara baik formal maupun non formal. Dalam pertunjukan Tingkilan dikenal juga istilah peningkil yaitu orang yang melagukan syair-syair lagu, baik itu hasil dari olah kreatifnya sendiri maupun syair lagu Tingkilan yang telah ada. Seorang peningkil memiliki kemampuan lebih selain bisa mengumandangkan lagu-lagu Tingkilan, juga bisa dengan cepat beradaptasi terhadap permintaan dari orang atau lembaga yang menanggapnya.

Di kabupaten Kutai Kartanegara sendiri hampir setiap kecamatan memiliki kelompok/grup Tingkilan yang merupakan kebanggaan bagi masyarakat pendukungnya. Hal ini menjadi menarik ketika kita berada dalam pergaulan global yang hampir sebagian besar musik yang disajikan berpijak pada musik populer yang mengacu pada trend dan trademark pasar. Oleh karena itu penulis tertarik untuk memaparkan tentang faktor-faktor pendorong kreativitas seniman Tingkilan Kutai Kalimantan Timur dengan pendekatan secara Etnomusikologis.

Jenis penelitian kualitatif dengan menggunakan metode penulisan secara deskriptif Analitik dan menggunakan pendekatan secara Etnomusikologis dipilih peneliti agar mendapatkan gambaran tentang kreativitas yang dilakukan oleh para seniman Tingkilan Kutai. Pendekatan Etnomusikologi digunakan untuk membahas musik tidak hanya pada musiknya saja/tekstual, tetapi juga mencakup seluruh aspek budaya yang ada kaitannya dengan musik tersebut/kontekstual (Nettl, 1964:5-7).

\section{PEMBAHASAN}

Tingkilan merupakan salah satu jenis kesenian musik masyarakat Kutai yang berasal dari perjalanan masuknya Islam ke Kutai. Tingkilan memiliki kesamaan dengan kesenian rumpun Melayu yang kemudian beralkulturasi dengan budaya-budaya lain yang ada di Kutai, sehingga berkembang menjadi tiga jenis gaya Tingkilan yaitu gaya Hulu Mahakam, gaya Hilir Mahakam/pesisir dan gaya Modern, masing-masing gaya tersebut memiliki karakter dan gaya yang berbeda-beda. Kreativitas dari para seniman Kutai tentu dapat digunakan untuk mempertahankan musik tradisi Kutai.

Perkembangan Tingkilan tidak terlepas dari beberapa faktor yang mempengaruhinya baik yang disebabkan oleh faktor eksternal atau faktor luar maupun faktor internal atau faktor dari dalam masyarakat Kutai itu sendiri. Faktor eksternal atau faktor luar yang mempengaruhi perkembangan musik daerah dapat disebabkan oleh letak geografis yang strategis, sejarah, kemajuan di bidang ilmu pengetahuan dan teknologi dapat mempengaruhi pandangan masyarakat tentang konsep hidup, adat, dan tradisi. Masyarakat di daerah pedalaman bertambah pengetahuannya melalui pendidikan atau sekolah, penyuluhan-penyuluhan yang dilakukan pemerintah, melalui para misionaris yang datang untuk menyebarkan agama, melalui media televisi, radio, dan lain-lain. Hal ini dengan sendirinya terjadi 
kontak yang menyebabkan perubahan terhadap pandangan hidup masyarakat desa dari yang sederhana menjadi lebih maju atau modern.

Salah satu contoh lagu Tingkilan yang hanya menggunakan vokal, Gambus dan kadangkala ditambah dengan Rebana/ Maruas dan belum mendapat hasil olah kreativitas dapat dilihat pada ilustrasi 1 .

Faktor internal yang mempengaruhi berkembangnya Tingkilan adalah adanya upaya dari para senimannya yang produktif untuk menciptakan karya-karya baru yang bisa mengakomodir dari selera masyarakat Kutai zaman sekarang. Selain itu masyarakatnya juga menganggap bahwa perkembangan tersebut adalah baik untuk pelestarian musik tradisi. Kesenian daerah merupakan warisan budaya yang layak untuk dilestarikan karena kesenian menunjukkan kepada kepekaan dan kelembutan perasaan khas manusiawi. Tingkilan sebagai salah satu musik tradisi yang dinamis

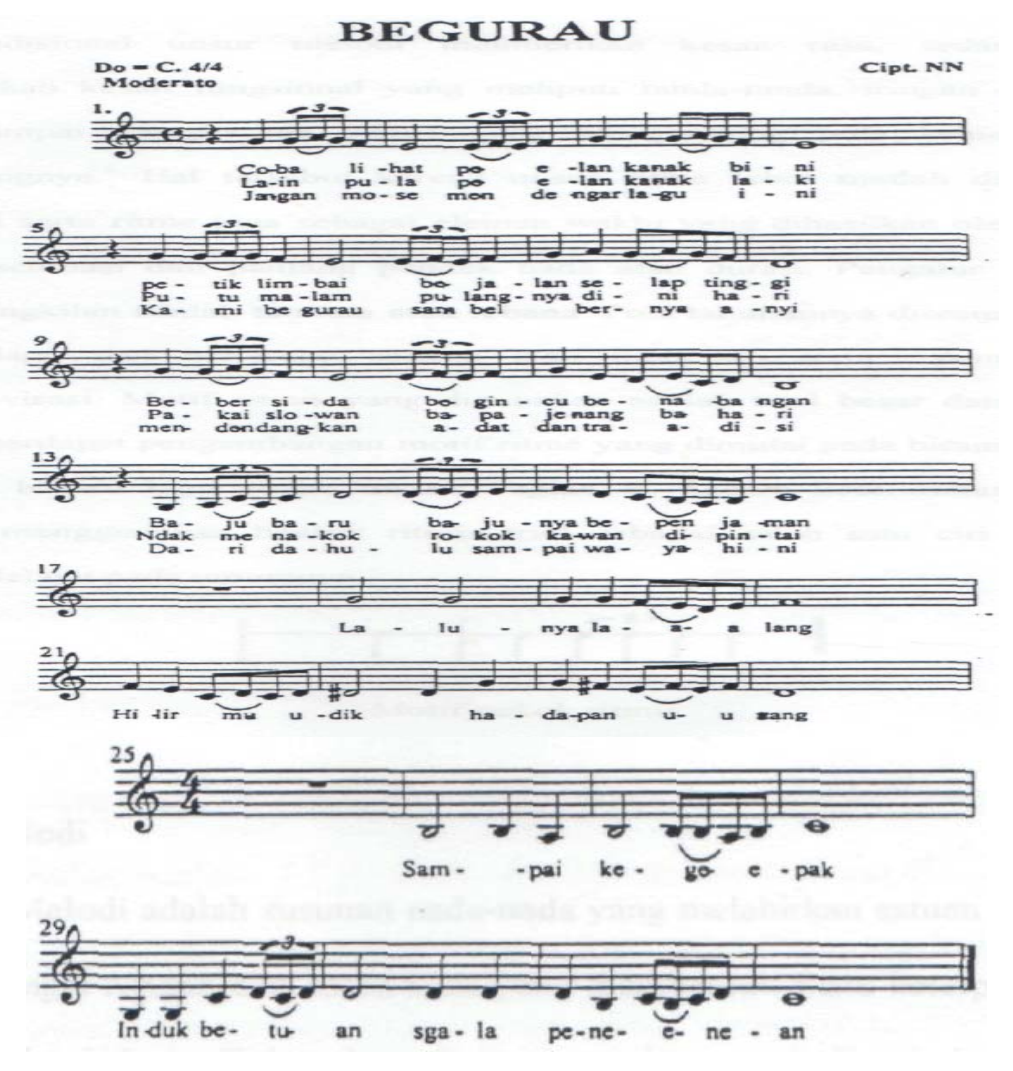

Ilustrasi 1

(Sumber: Transkripsi Eli Irawati, 2012) menerima perkembangan zaman, hal ini terlihat dari masuknya beberapa idiom musik baik dari zaman penjajahan maupun zaman sekarang sebagai bentuk kreativitas seniman setempat guna mempertahankan eksistensi Tingkilan, mengemas Tingkilan dengan pola garapan baru dengan cara penambahan beberapa instrumen seperti biola dan suling dalam komposisi lagu, menggunakan pengeras suara dalam pertunjukannya dan durasi lagu yang disesuaikan dengan keinginan penonton.

Hasil kreativitas seniman Tingkilan membuat aransemen sesuai dengan kondisi zaman dan keinginan pasar sesuai dengan ketrampilan dan pengetahuan yang mereka miliki tanpa menghilangkan ciri khas. Penggarapan dilakukan dengan memakai sistem oral, spontanitas, dan improvisasi, sehingga faktor latar belakang seniman Tingkilan sangat mempengaruhi hasil dari olah kreativitas tersebut. Mengingat yang dominan secara garapan musik dalam pertunjukan Tingkilan adalah Gambus, maka tidak mengherankan apabila aransemen dapat mengakomodir segala macam idiom musik. Hal ini dikarenakan Gambus bisa distem layaknya gitar atau instrumen sejenis dan jangkauan oktaf Gambus memungkinkan pemainnya untuk lebih bisa mengeksplorasi permainan.

Contoh hasil olah kreativitas seniman Kutai pada Lagu Bergurau dengan menambahkan beberapa instrumen seperti Suling, Biola, Cello, dan Rebana, dengan pola garapan musik yang sudah mengalami perkembangan dapat dilihat pada ilustrasi 2 . 


\section{BEGURAU}

Do $-\mathrm{C} \cdot 4 / 4$

Cipt. NN
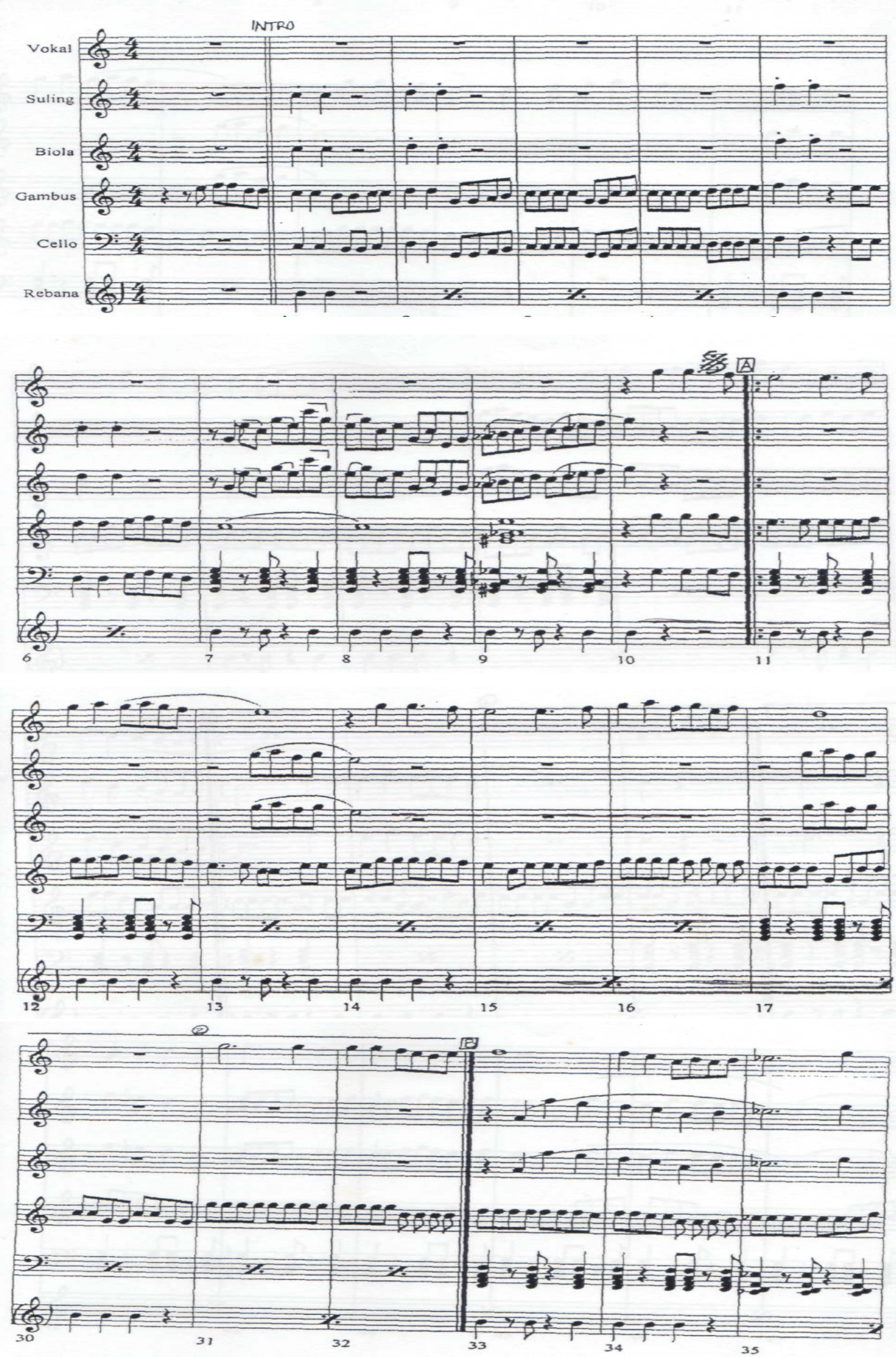

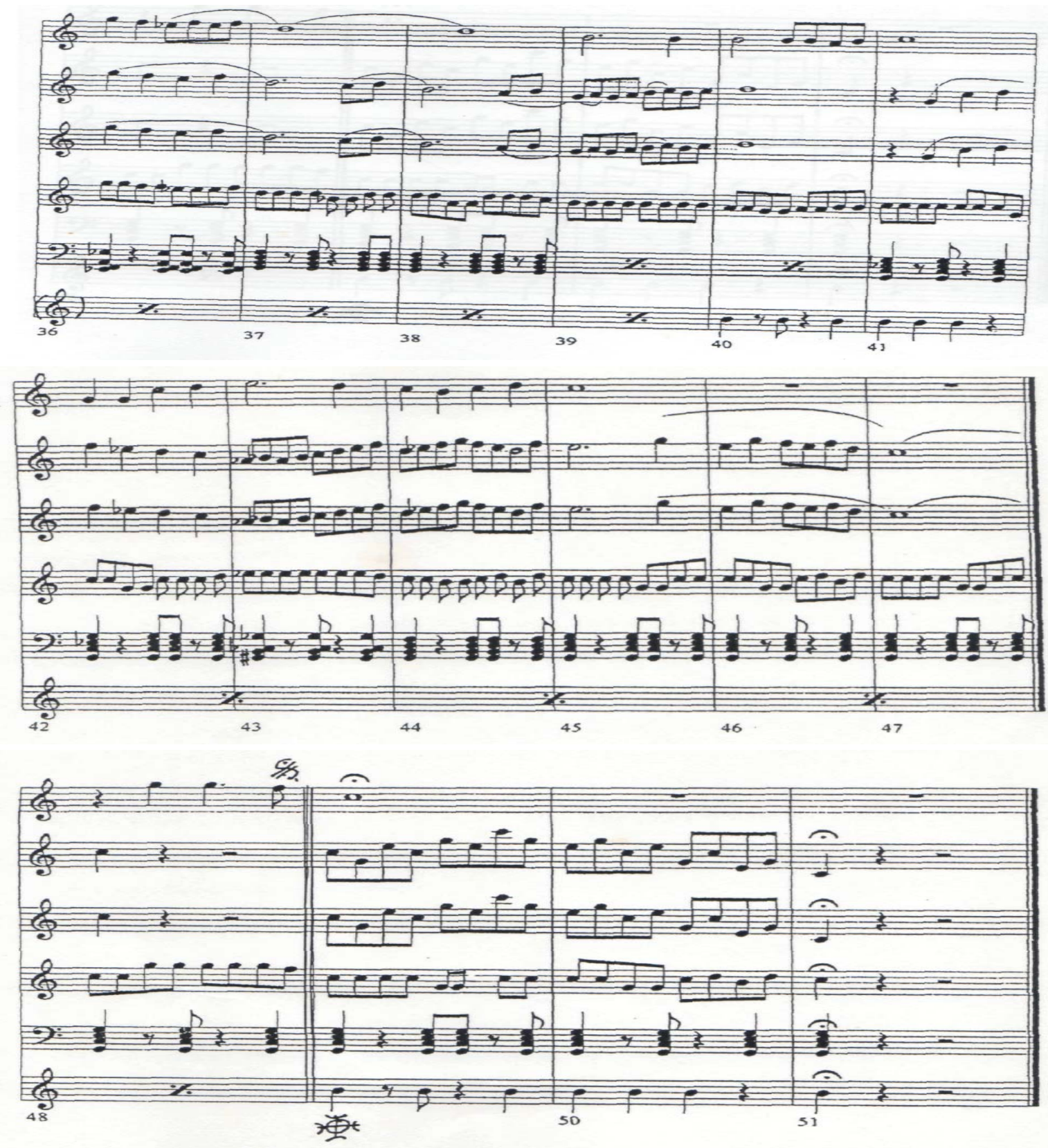

Ilustrasi 2

(Sumber: Transkripsi Eli Irawati, 2012)

\section{Kreativitas Seniman Tingkilan}

Musik biasa juga dikatakan sebagai perilaku sosial yang kompleks dan universal. Setiap masyarakat memiliki musik, oleh karenanya semua masyarakat dari berbagai lapisan atau golongan adalah potret dari kehidupan musikal yang dihasilkan. Keheterogenan etnis dan bahasa yang ada di Indonesia mempengaruhi pula dalam kehidupan bermusiknya, masing-masing daerah memiliki ciri dan pola tersendiri dalam mempertunjukan hasil budayanya khususnya musik etnis. Musik-musik dari daerah tersebut mempunyai fungsi dan tujuan tertentu apabila musik itu dipertunjukkan, sebagai contoh Tingkilan lengkap dengan tarian Jepennya dipertunjukkan untuk memeriahkan berbagai macam acara yang dilakukan masyarakat Kutai seperti menyambut tamu-tamu kehormatan atau membuka pergelaran festival kesenian dae- 
rah Erau dan lain sebagainya.

Ada beberapa aspek pembentuk kebudayaan Kutai khususnya Tingkilan, di antaranya adalah budaya Pantai atau budaya orang Melayu yang bernafaskan Islam, budaya peninggalan Kesultanan Kutai, Sambaliung, Gunung Tabur, Bulungan dan Pasir Belengkong, serta budaya suku Pedalaman. Hal ini tidak hanya terjadi di masyarakat Kutai saja, tetapi juga di daerah-daerah lain di nusantara. Musik sebagai bagian dari seni adalah salah satu cara untuk menggambarkan dan mengomunikasikan berbagai hal yang ada dalam masyarakat. Seni juga merupakan suatu bentuk komunikasi yang digunakan orang dalam menyampaikan segala macam keluhan, kejengkelan, kesenangan, kegembiraan, dan lain sebagainya. Oleh karenanya tidak jarang seni disebut sebagai ekspresi emosional dan cerminan masyarakat dalam suatu budaya. Seni dikomunikasikan dalam bentuk karya yang beragam wujudnya baik itu seni pertunjukan, seni rupa dan seni-seni yang lainnya.

Seni biasanya tercipta bermula dari imajinasi seorang seniman yang dituangkan dalam berbagai wujud kreativitas. Seniman sangat lekat dengan pengalaman empiris yang dituangkannya lewat karya yang diciptakannya. Seniman juga seorang pencipta yang sangat peka dalam mengamati benda dan peristiwa-peristiwa di sekelilingnya, baik itu peristiwa sosial, politik, ekonomi, budaya, dan lain sebagainya. Kesan-kesan yang dikumpulkan baik pengalaman pribadi maupun dari lingkungan ini kemudian diolah dan dipadukan dalam wujud karya seni yang syarat akan makna.

Seniman memiliki cara spesifik dalam berkomunikasi dan mengomunikasikan gagasan, rasa, serta berbagai fenomena kebudayaan, sosial dan kemanusiaan. Seniman berbicara dan berkomunikasi bukan secara verbal, melainkan lewat rasa dalam bentuk sombol-simbol. Dalam seni musik, seniman berbicara lewat simbol-simbol bunyi, ritme, budaya, sosial dan sebagainya Waridi 2006:204). Oleh karenanya ketika seorang seniman Tingkilan mengartikan sebuah fenomena kebudayaan masyarakat Kutai, seniman tersebut tidak sekedar berbicara tentang kebudayaan masyarakat seperti bahasa verbal dan membuatnya menjadi karya tulis ilmiah yang syarat akan deskripsi dan analisis. Tetapi bagi seniman Tingkilan mereka manfaatkan hal tersebut sebagai alat referensi untuk membangun imajinasi agar terwujud sebuah karya seni.

Karya seni yang berwujud inilah kemudian dapat kita nikmati baik lewat pendengaran, penglihatan, dan lain sebagainya. Dari sinilah kemudian karya tersebut mulai memasuki area publik, di mana masyarakat mulai menilai apakah karya tersebut bisa diterima atau tidak. Apabila karya tersebut menjadi populer, bahkan legendaris barulah kita akan mencari, menggali dan ingin mengetahui bagaimana sebuah karya tersebut dapat tercipta. Demikian pula yang terjadi dalam Tingkilan, penciptanya sampai saat ini belum diketahui siapa yang menciptakan karena karya tersebut berkembang sesuai dengan perkembangan masyarakat Kutai.

Tingkilan sebagai hasil perpaduan musik yang masuk ke wilayah Kalimantan Timur berabad-abad yang lalu, serta sudah bersentuhan dengan berbagai macam budaya yang ada sehingga menghasilkan produk hasil akulturasi dari beragam idiom musik seperti pengaruh musik melayu/Islam, penjajahan atau musik keroncong jenis langgam yang berpadu dengan cita rasa musikal suku Kutai. Melihat dari arus migrasi dan populasi yang mendiami propinsi Kalimantan Timur, baik dari segi pengaruh kerajaan Hindu Mulawarwan, Kerajaan Goa dari Bugis dan juga pencampuran penduduk yang ada di wilayah suku Kutai tinggal, memberikan aneka ragam kebudayaan. Kebudayaan yang menunjuk- 
kan sederetan sistem pengetahuan yang dimiliki bersama, kebiasaan-kebiasaan, nilainilai, interaksi sosial, hukum-hukum adat, dan simbol-simbol yang berkaitan dengan tujuan seluruh anggota masyarakat menjadikan masyarakat Kutai dapat berbaur dengan segala keanekaragaman tersebut. Hal ini mempengaruhi dari segi penciptaan musik khususnya Tingkilan.

Tingkilan dalam masyarakat Kutai dipengaruhi pula dari segi letak geografis, di mana di daerah Kutai mengenal istilah Hulu dan Hilir. Hulu adalah untuk menyebut suatu masyarakat yang mendiami wilayah pedalaman dan biasanya di sesuaikan dengan aliran sungai Mahakam. Budaya masyarakat Kutai yang tinggal di Hulu masih bersifat komunal dan kegotongroyongan masih berjalan sesuai dengan tatanan adat yang berlaku. Oleh karena itu tampilan Tingkilan lebih terlihat masih sangat sederhana, seperti dari segi pengolahan aransemen lagu dan penggunaan instrumen.

Tingkilan gaya Hulu atau pedalaman biasanya menggunakan instrumen musik Gambus sebagai melodi, ditambah dengan rebana atau tamtam sebagai tabuhan yang bersahut-sahutan (bertingkah). Biasanya pemain Gambus sambil menjadi peningkil atau dapat pula ditambah dengan seorang penyanyi wanita atau laki-laki yang bernyanyi dengan pantun yang mereka buat secara spontanitas dengan tetap pada pola sindiran dan bersahut-sahutan dengan durasi penyajian tidak terbatas serta kadangkala hanya bermain instrumenal saja, terutama pada saat mengiringi tarian Jepen.

Tingkilan gaya Hilir adalah para penduduk Kutai yang mendiami wilayah pesisir dan berada di daerah yang maju/berada di aliran Hilir sungai Mahakam. Budaya masyarakat Hilir lebih kompleks karena secara langsung bersentuhan dan berinteraksi dengan para pendatang yang datang ke Kalimantan Timur dengan berbagai tujuan. Seperti kita ketahui bahwa wilayah masyarakat Kutai tinggal banyak terdapat berbagai macam sumber daya alam yang potensial untuk dikembangkan secara profesional. Interaksi tersebut melahirkan berbagai macam bentuk produk budaya dan bahkan mempengaruhi budaya yang telah ada, salah satunya Tingkilan.

Perkembangan budaya tradisional hanya bersifat perkembangan sintagmatis, yaitu pluralisme budaya ditampakkan lebih dalam perbedaan variasi atau cengkok semata-mata dan tidak mengubah polanya. Bentuk penyajian Tingkilan mengalami penambahan atau variasi dalam penyajian antara kelompok yang satu dengan kelompok yang lainnya. Namun hal ini tidak mengurangi maupun menghilangkan pola atau bentuk pokok yang menjadi ciri khas dasar Tingkilan. Bagi para pelaku, khususnya seniman Tingkilan membuat kreasi atau menambahkan instrumen dalam penyajiannya berpedoman pada prinsip dasar Tingkilan yaitu pada Gambus Kutai dan Peningkil. Mereka berpendapat selama masih menggunakan Gambus sebagai instrumennya, maka musik yang diolah tersebut termasuk Tingkilan. Tingkilan yang ada di wilayah Hilir terutama di wilayah pesisir seperti Kutai Kartanegara, sudah mengalami banyak perkembangan, baik dari cara pola garap musikal maupun dari segi instrumen yang digunakan. Hal ini secara tidak langsung mempengaruhi pola pertunjukan Tingkilan, sehingga terdapat penambahan instrumen musik seperti gitar, cuk, cak, cello, contrabass, dan tidak menggunakan ketipung sebagai tabuhan ritme.

Apabila selintas mendengarkan Tingkilan terkesan seperti musik Keroncong jenis langgam, begitu pula dengan penyanyi yang mendendangkan syair lagulagu Tingkilan sepintas cengkok yang digunakan mirip dengan gaya menyanyi orang Melayu tetapi sudah ada campuran dengan Keroncong yang memiliki pola tapi bebas berimprovisasi. Oleh karena itu Tingkilan terbentuk karena adanya perpa- 
duan antara musik Melayu, cita rasa lokal dan Keroncong jenis langgam yang dapat bersinergi dengan baik. Selain dengan dua gaya tersebut sekarang ada pula istilah Tingkilan modern yang sedang ngetrend di kalangan anak muda. Gaya ini merupakan perkembangan dari jenis Tingkilan yang telah ada sebelumnya. Pola penyajian dari segi syair dan pola sajian Peningkil dalam membawakan lagu, masih menggunakan pola berpantun yang berisi sindiran, tetapi dalam pemilihan kata-kata lebih bervariasi dan lugas. Para vokalis juga masih bisa berpantun dengan spontanitas tetapi biasanya mereka juga sudah membuat struktur lagunya serta mengetahui konsep acara yang sedang berlangsung.

Perkembangan selanjutnya adalah Tingkilan gaya modern dalam pola garapan misalnya kita bisa melihat mereka mengolaborasikan berbagai macam genre musik populer kedalam Tingkilan, seperti idiom musik Dangdut, Jazz, Blues, Pop, Keroncong dan lain-lain. Instrumen yang digunakan lebih bervariatif seperti Djimbe untuk menggunakan fungsi ketipung dan rebana, elektone atau orgen untuk menggantikan suara cello, cak, cuk dan lain sebagainya. Suatu ide atau gagasan tertentu dapat merupakan pesan yang ingin dikomunikasikan oleh si senimannya kepada penikmat seni untuk mendapatkan respon atas kehadiran karya seni tersebut yang sekaligus juga dapat menangkap pesan yang disampaikan (Soedjono, 2006:126).

Demikian pula dengan hasil olah kreativitas seniman Kutai yang penuh dengan gagasan, hasrat,dan pengalaman empiris tertentu yang ingin dikomunikasikan lewat karya musik Tingkilan.

Lahirnya gaya dengan pola sajian yang berbeda ini sama-sama memiliki tujuan yang sama, yaitu melestarikan Tingkilan yang mereka akui sebagai musik milik orang Kutai. Tingkilan gaya modern banyak mengalami perkembangan bahkan perubahan baik dari segi penyajian maupun garapan musiknya. Kreativitas yang dilakukan oleh seniman Kutai merupakan salah satu bentuk untuk meminimalisir kebosanan para pelaku Tingkilan itu sendiri baik itu para peningkil maupun para pemain musik, agar tetap mengikuti trend musik dan perkembangan jaman. Selain itu adalah sebagai ajang kompetisi kreativitas dan komposisi dari para seniman Tingkilan agar dapat dianggap paling revolusioner.

Setiap seniman memiliki cara yang berbeda dalam mengolah musik dan pasti mempunyai ciri khas tersendiri akibat segala macam pengaruh lingkungan, pengalaman empiris dari seniman itu sendiri agar karyanya dapat dinikmati oleh semua orang. Sebuah proses dapat berjalan dengan mudah dan cepat, tetapi bisa juga memakan waktu yang cukup lama atau terhenti di tengah jalan hingga akhirnya karya tersebut tidak pernah terwujud (Djelantik, 1999:57). Kebebasan berkreasi yang dilakukan para pelaku Tingkilan membawa dampak dan suasana baru dalam penciptaan musik baru walaupun masih dikatakan dalam kategori Tingkilan modern.

\section{Pendorong Munculnya Kreativitas Seniman Tingkilan}

Suatu budaya musik mencakup suatu gagasan-gasasan dan tindakan karena musik adalah suatu gejala manusia, untuk manusia dan mempunyai fungsi sosial dalam situasi sosial, seperti yang dikatakan Brown bahwa musik merupakan sumbangan aktivitas suatu bagian secara keseluruhan dalam suatu masyarakat. Ini berarti bahwa musik itu akan menduduki bertahan apabila masyarakat pendukungnya menganggap bahwa musik merupakan suatu kebutuhan (Brown, 1980:201).

Tingkilan sebagai bagian yang penting dalam mensukseskan suatu acara merupakan sebagai pembentuk identitas buda- 
ya masyarakat Kutai dan kreatifitas yang dihasilkan merupakan sebagai sumbangan kepada keseluruhan sistem sosial tersebut. Kreativitas tidak begitu saja muncul banyak hal yang melatarbalakangi, di antaranya adanya aspek pendorong kreativitas tersebut. Munculnya suatu kreativitas dalam seniman Kutai terbagi dalam dua faktor yaitu faktor internal dan faktor eksternal.

Faktor internal meliputi agen perubah dari seniman Tingkilan yang membawa perubahan secara musikal dari karya yang berbeda dari model sebelumnya dan menjadi perhatian banyak orang. Faktor keturunan yang dianggap memberikan pengaruh secara alami karena adanya bakat warisan mengikuti ikatan pertalian darah. Faktor lingkungan sebagai area yang membesarkan para kreator Tingkilan yang tentu saja turut memberikan sumbangan berbagai pemikiran-pemikiran baru tentang perkembangan musik secara global.

Pengaruh lain yang tidak kalah penting adalah lingkungan di mana dapat mempengaruhi perkembangan musikal individu yang tinggal di lingkungan tersebut. Sebagai contoh Lemong seorang seniman otodidak yang terlahir bukan dari keluarga seniman Tingkilan, tetapi lingkungan tempat tinggalnya merupakan lingkungan para pelestari Tingkilan, hal ini membentuk pemahaman dan tidak asing lagi dengan Tingkilan, sehingga mempelajari musik dengan cara melihat, memperhatikan, dan mengikuti permainan yang dimainkan oleh para pendahulunya. Seniman yang memiliki bakat seni ataupun mewarisi darah seni orang tuanya jika tidak ditempatkan pada lingkungan yang benar tidak akan berkembang dengan baik. Lingkungan adalah sebuah keadaan yang mengelilingi kita, berhubungan dengan alam di mana kita tinggal, orang-orang yang hidup dengan segala aktivitas yang terjadi, kegiatan sehari-hari termasuk berkesenian. Lingkungan yang benar dalam konteks ini merupakan ling- kungan yang mendukung gerak aktivitas seseorang dengan bakat yang dimilikinya.

Faktor eksternal berkaitan dengan lingkungan di luar kehidupan seorang seniman di antaranya adalah kemajuan teknologi dan informasi baik lewat media cetak maupun elektronik, selera masyarakat yang sudah mulai bergeser atau menyukai hal-hal baru, budaya massa atau global yang masuk ke wilayah setempat, dan adapula faktor ekonomi yang mempengaruhi produktivitas senimannya, dalam hal ini efisiensi pemain. Hal-hal tersebut membentuk serangkaian proses untuk mengungkap dua konsep pemikiran yang melatarbelakangi terbentuknya Tingkilan dengan berbagai macam gaya sebagai sebuah produk seni pertunjukan.

\section{Kreativitas Penciptaan Lagu-lagu Tingkilan Kutai}

Mewujudkan sebuah karya seni bermutu diperlukan kreativitas tinggi untuk konsep yang digarap. Kematangan konsep akan mewujudkan sebuah karya yang maksimal, dinamis dan dapat diterima oleh masyarakat pendukungnya. Begitu pula dalam hal proses penciptaan lagu-lagu Tingkilan. Para seniman setempat biasanya menciptakan lagu-lagu tersebut terinspirasi dari apa yang sedang terjadi baik itu dalam dirinya sendiri maupun lingkungan sekitar.

Inspirasi penciptaan lagu-lagu Tingkilan dilakukan seniman setempat dengan melihat fenomena budaya dan sosial yang ada dilingkungan setempat dan mewujudkannya dalam bentuk garapan musik. Melalui inspirasi yang didapat lewat pikiran, imajinasi, merasakan, menanggapi dan menafsirkan lewat nada-nada yang dirangkai menjadi melodi yang selanjutkanya menjadi garapan komposisi Tingkilan. Ideide kreativitas tidak akan pernah muncul manakala kita tidak berusaha menciptakan 
atau menggalinya. Salah satu cara adalah dengan melakukan eksplorasi yaitu sebuah percobaan untuk mengakumulasi dan mengakomodasi keleluasaan dari kemungkinan untuk berkarya berdasarkan keleluasaan pilihan dengan variabel yang digunakan.

Seniman sebenarnya tidak menyadari betapa luasnya pemahaman dan daya khayal mereka menuju ke dalam ruang yang sebelumnya belum dikenal. Keberanian dalam mengungkapkan perasaan, kepenatan yang seakan membelenggu dan menutup daya kekuatan imajinasi, kepekaan kita terhadap musik-musik yang telah akrab ditelinga kita akan membantu membuka cakrawala berpikir dalam menuangkan ide ke dalam sebuah karya baru. Setiap manusia mempunyai tingkat pemahaman dan daya khayal yang berbeda tergantung dari pemahaman yang dimilikinya. Tingkat ketajaman tergantung pada latar belakang dan proses kreatif yang melatarbelakanginya, sehingga tidak akan sama antara manusia yang satu dengan manusia lainnya dalam mencapai proses kreatifnya.

Setelah tahapan eksplorasi biasanya seorang seniman mencoba untuk berimprovisasi memberikan kesempatan yang lebih besar bagi imajinasi, seleksi, dan mencipta dari pada tahap eksplorasi. Hal yang dilakukan dalam eksperiman, hal yang pertama kali dilakukan adalah mencari benang merah jalinan nada dalam komposisi Tingkilan. Semua ini dilakukan agar nantinya sewaktu pembuatan musik serta penggabungkan instrumen yang digunakan dalam komposisi dapat bersinergi dengan baik.

Pada tahapan improvisasi terdapat kebebasan yang lebih bagi setiap pemain Tingkilan untuk mengeksplorasi dan menginterpretasikan segenap kemampuannya dan tetap pada pola dasar yang telah di tetapkan sang komposer. Melalui improvisasi seseorang diberikan kebebasan dalam meng- olah maupun menentukan ekspresi di dalam mengembangkan pola permainannya. Di sinilah biasanya kreativitas seorang seniman dan pemain terlihat, yaitu dengan membentuk komposisi dari hasil akumulatif pengalaman empiris apa yang pernah mereka rasakan, pikirkan dan apresiasi terhadap musik di luar Tingkilan.

Pembuatan sebuah komposisi musik khususnya Tingkilan membutuhkan kerja ekstra dalam artian seorang seniman harus benar-benar melakukan observasi ke masyarakat Kutai sebagai pemilik dari musik ini. Hal ini dimaksudkan agar karya tersebut nantinya dapat diterima oleh masyarakat pemiliknya tanpa menghilangkan ciri khas yang dimiliki oleh musik tersebut. Seniman mempunyai cara yang unik untuk berpikir dan bertindak secara kreatif, mereka merupakan seorang kreator seni yang memiliki kreativitas yang tinggi dalam menghasilkan sebuah karya seni karena setiap nada yang dirangkai menjadi melodi memiliki nilai historis masing-masing yang hanya dimengerti oleh si seniman tersebut. Sebuah komposisi musik dalam hal ini Tingkilan merupakan hasil dari sebuah proses yang dialami oleh seniman Kutai dari hasil mencoba untuk membuat karya dengan cara mengekplorasi segenap kemampuannya baik secara musikal maupun non musikal yang digabungkan menjadi suatu bentuk karya seni yang dapat diterima dan disenangi masyarakat pendukungnya.

\section{Perkembangan Tingkilan Modern}

Kreativitas seniman Kutai khususnya dalam Tingkilan tergantung dari untuk apa musik tersebut di pertunjukkan, dalam hal ini ada karya yang berorentasi pelestarian dan ada karya yang berorentasi perkembangan. Tingkilan untuk pelestarian dimaksudkan bahwa penciptaan karya seni tidak 
melihat apakah masyarakat atau pasar membutuhkan karya itu atau tidak, karena yang terpenting adalah Tingkilan tersebut ditampilkan sebagai salah satu cara untuk memperkenalkan kepada generasi muda Kutai. Adapun perkembangan Tingkilan, biasanya membuat bentuk baru dengan cara mengemas bentuk pertunjukan Tingkilan sesuai dengan selera pasar dan biasanya dimasukkan berbagai macam idiom musik dan juga menambahkan unsur teknologi multimedia sebagai salah satu daya tarik bagi generasi muda.

Sebagai contoh akhir-akhir ini banyak dijumpai lagu dan garapan Tingkilan yang diunggah ke internet (youtube), hal ini merupakan salah satu ajang promosi memperkenalkan Tingkilan ke masyarakat di luar suku Kutai. Kemudahan sistem promosi tersebut membuat seniman setempat berlomba-lomba membuat karya agar bisa memperkenalkan sanggar ataupun seniman secara individu.

Teknologi dan informasi berperan untuk memenuhi nilai praktis sekaligus ekonomis di mana seorang seniman tidak harus membayar produser dan studio rekaman untuk sebuah promosi, karena setiap orang memiliki handphone yang fiturnya memungkinkan setiap orang untuk membuat video untuk keperluan promosi. Teknologi dalam kasus ini ikut andil dalam perannya yang lain yaitu sebagai dokumentasi bagi komposer untuk merealisasikan ide dan karyanya. Dokumentasi ini yang selanjutnya akan menjadi umpan balik dan mempengaruhi karya selanjutnya. Ada pula cara lain untuk membuat sebuah komposisi Tingkilan yaitu dengan memanfaatkan perangkat lunak komputer sebagai salah satu media transpormasi yang dapat dengan mudah membuat musik dengan program sibelius, finale, dan lain sebagainya.

Teknologi menyediakan beraneka ragam program-program pembuat musik di mana orang-orang yang aktif bergelut dalam musik dan ingin berkreasi secara mandiri mampu terpenuhi dengan adanya program-program pengolah musik tersebut. Program pembuatan musik di komputer menyediakan berbagai jenis sampel suara instrumen musik dari berbagai macam belahan dunia, yang mana untuk berekplorasi tidak perlu ketrampilan hebat dalam bermain musik, tidak perlu alat dan studio rekaman yang lengkap, dan lain-lain, karena yang terpenting adalah cukup melatih daya imajinasi dan memperluas wawasan bermusik untuk memunculkan ide-ide kreatif, seseorang sudah dapat menghasilkan musik melalui teknologi dan bahkan menjualnya. Pada situasi seperti ini bantuan teknologi menjadi alternatif yang cukup memuaskan, karena si seniman tidak perlu menghadirkan para pemusik Tingkilan.

Pembuatan contoh musik melalui program musik komputer yaitu Finale/Sibelius sangat membantu efektifitas pembuatan musik melalui program yang didapat dengan merancang musik sesuai dengan master karena telah tersedia beberapa instrumen sebagai data utama musik tersebut. Hasil pengerjaannya dapat disimpan dalam bentuk format lagu, sehingga lagu tersebut menjadi pengingat bentuk musik yang telah kita ciptakan dari melodis dan ritmisnya. Contoh musik yang telah dibuat akan direalisasikan dengan para pendukung yakni saat prosesi latihan bersama. Hal ini secara tidak langsung membuat para seniman dan orang awam yang tertarik terhadap Tingkilan dapat berkreasi tanpa mengenal batasan gender, usia, status sosial, dan lain sebagainya. Oleh karena itulah teknologi tidak pernah lepas dari setiap kreativitas Tingkilan.

Kesenian seperti Tingkilan kalau ingin tetap dicintai masyarakatnya harus mengikuti selera masyarakat Kutai sebagai penyokong sebuah eksistensi dan juga sebagai faktor munculnya kreativitas. Tuntutan 
masyarakat juga menjadi salah satu pemicu yang memotivasi seniman penggarap untuk selalu kreatif, terutama di daerah pesisir atau perkotaan yang cenderung terpengaruh oleh beragam jenis musik populer. Berbagai macam cara dilakukan para seniman Tingkilan untuk memenuhi selera masyarakat Kutai, salah satunya adalah mengeksplor bunyi dari berbagai instrumen dan mengkolaborasikannya dalam garapan, mendengarkan beragam jenis musik, yang memungkinkan untuk dijadikan modelmodel garapan baru dengan konsep yang lebih segar. Musik-musik itu bisa berasal dari Kutai, Jawa, India dan lain sebagainya. Seorang seniman Tingkilan diharapkan mampu menyerap hal-hal yang menjadi inspirator untuk kemudian mengemasnya menjadi sesuatu yang menarik, tanpa melepas ciri dari Tingkilan itu sendiri.

Ide kreatif juga dapat lahir karena adanya kontak budaya dari seniman setempat dengan budaya yang ada di luar Kutai, hal ini bisa terjadi secara sengaja atau tidak disengaja. Salah satu contohnya adalah seorang seniman Tingkilan melanjutkan studi ke jurusan Musik Fakultas Seni Pertunjukan Institut Seni Indonesia Yogyakarta. Di sini secara sengaja ia mempelajari ilmu musik, baik itu keterampilan bermain instrumen dengan teknik-teknik yang telah ada maupun mempelajari teori musik yang berhubungan dengan cara mengkomposisi sebuah karya musik. Adapun hal yang tidak disengaja adalah seniman Tingkilan tersebut masuk dalam sebuah komunitas yang ada di Yogyakarta yang notabene merupakan kota pelajar, kota wisata, kota budaya, dan lain sebagainya. Adanya interaksi sosial antara si seniman Tingkilan dengan seniman dari daerah lain di luar budayanya membuat mereka belajar banyak hal dan seringnya membuat garapan bersama atau kolaborasi, membuat para seniman tersebut secara tidak langsung menyerap banyak ilmu dan pengetahuan tentang bagaimana membuat sebuah komposisi musik.
Bentuk kreativitas yang tersaji dalam komposisi musik khususnya Tingkilan, akhirnya juga berhubungan dengan penghasilan yang diterima. Para seniman yang berkreasi lewat komposisi Tingkilan cenderung memilih untuk mengikuti keinginan masyarakat daripada mempertahankan keutuhan jenis Tingkilan dengan pola lama. Hal ini sebenarnya sangat manusiawi karena biar bagaimanapun mereka harus memenuhi kebutuhan hidup keluarga, sementara masyarakat sebagai penikmat seni berhak memilih mana yang mereka suka. Semakin tinggi minat masyarakat terhadap musik mereka tentu akan semakin besar pula pendapatan si seniman. Ketika seniman melakukan pementasan ada hal yang tidak bisa kita ingkari yaitu keinginan untuk menghibur orang yang menonton. Hal ini pada akhirnya menyebabkan seniman membuat karya untuk memenuhi kebutuhan hidup hingga dikatakan seni diciptakan untuk pasar. Tetapi tujuan dari para seniman Tingkilan bukan hanya mementingkan segi komersilnya saja, melainkan ada keinginan untuk pelestarian agar generasi muda mau mempelajari dan melestarikan musik tradisi.

\section{PENUTUP}

Tingkilan sebagai musik tradisi diwariskan secara oral atau langsung dari generasi ke generasi. Tingkilan bersifat terbuka menerima pengaruh dari luar dan dalam, sesuai dengan kebutuhan, karena itulah di dalam musik ini terdapat berbagai macam perpaduan idiom musik seperti adanya pengaruh musik Keroncong jenis langgam, musik Melayu, musik Selawatan. Selain itu, peranan syair lagu dalam Tingkilan memiliki peranan yang penting dalam menyampaikan nasihat atau sindiran bagi para masyarakat Kutai khususnya para generasi muda, oleh karena itulah eksistensi Tingkilan Kutai sampai saat ini msih terjaga. 
Faktor-faktor yang mempengaruhi kreativitas Tingkilan tidak terlepas dari beberapa faktor yang mempengaruhinya baik yang disebabkan oleh faktor eksternal atau faktor luar maupun faktor internal atau faktor dari dalam. Faktor eksternal atau faktor luar yang mempengaruhi perkembangan musik daerah dapat disebabkan oleh letak geografis yang strategis, sejarah, kemajuan di bidang ilmu pengetahuan dan teknologi, mempengaruhi pandangan masyarakat tentang konsep hidup, adat, dan tradisi. Faktor internal yang mempengaruhi berkembangnya Tingkilan adalah adanya upaya dari para senimannya untuk produktif menciptakan karya-karya baru yang bisa mengakomodir dari selera masyarakat Kutai zaman sekarang yang tentunya membutuhkan sentuhan olah kreativitas dari para senimannya. Kreativitas seniman Kutai khususnya dalam Tingkilan akhirnya diperuntukkan tergantung dari untuk apa musik tersebut dipertunjukkan, dalam hal ini ada karya yang berorentasi pelestarian dan ada karya yang berorentasi perkembangan.

\section{Daftar Pustaka}

A. A. M. Djelantik

1999 Estetika Sebuah Pengantar. Bandung: MSPI.

Brown, A.R Radcliffe

1980 Struktur dan Fungsi dalam Masyarakat Primitif, terj. Abd. Razak Yahya.
Kuala Lumpur: Dewan Bahasa dan Pustaka.

Nettl, Bruno

1964 Theory and Method in Ethnomusicology. Newyork:The Free Press of Glencoe Collier-Macmillan Limited.

Soeprapto Soejono

2006 "Dialektika Seni: Proses Komunikasi Informasi dan Tanggapan Estetis" dalam Y. Sumandiyo Hadi, et.al, $R i$ nengganing: Pak Bandem Yang Ngebyar. Yogyakarta: BP ISI Yogyakarta.

Waridi

2006 “Mencermati Musik Lagaligo Karya R. Supanggah: Pendekatan, Artikulasi, Instrumenasi, dan Pijakan Reertoar" dalam Y. Sumandiyo Hadi, et. al. Rinenggaring: Pak Bandem Yang Ngebyar. Yogyakarta: ISI Yogyakarta.

Nara Sumber:

Sawiyah, 50 tahun.

Seniwati peningkil dari Kutai Kartanegara.

Amran, 55 tahun.

Komposer dan Seniman Tingkilan dari Samarinda.

Aji Jon Askar, 65 tahun.

Komposer dan Seniman Tingkilan dari Muara Muntai. 